\title{
Rates of deliveries with vacuum extraction and the relationship between maternal age, parity and neonatal APGAR scores
}

\section{Vakumla doğum oranları ve maternal yaş, parite ve neonatal Apgar skorları ile ilişkisi}

\author{
Şükrü BUDAK ${ }^{1}$, Muzaffer TEMUR ${ }^{2}$, Yasemin KILIÇ ÖZTÜRK ${ }^{3}$, Özgür YILMAZ ${ }^{4}$, Hese COSAR $^{5}$, \\ Pelin ÖZÜN ÖZBAY ${ }^{6}$, Engin KORKMAZER ${ }^{2}$, Emin ÜSTÜNYURT $^{2}$ \\ ${ }^{1}$ Diyarbakır Kadın Doğum ve Çocuk Hastalıkları Hastanesi Kadın Hastalıkları ve Do ğum Kliniği, Diyarbakır \\ ${ }^{2}$ Bursa Şevket Yllmaz Ĕ̆itim ve Araştırma Hastanesi Kadın Hastalıklarl ve Doğum Kliniği, Bursa

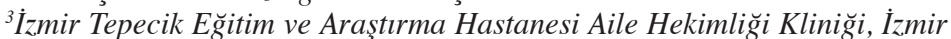 \\ ${ }^{4}$ Manisa Merkezefendi Devlet Hastanesi Kadın Hastalıkları ve Doğum Kliniği, Manisa \\ ${ }^{5}$ Manisa Merkezefendi Devlet Hastanesi Çocuk Hastalıkları Kliniği, Manisa \\ ${ }^{6}$ Aydin Özel Liva Hastanesi, Aydin
}

\section{ABSTRACT}

Objective: The aim of this study is to determine the rate of vacuum extraction, and its relationship with parity and intrauterine fetal condition.

Methods: This study was conducted at Diyarbakır Maternity Hospital in Turkey during 2012 with 20050 newborns who were delivered at the obstetrics/gynecology clinics. Two hundred and forty-nine of them were vacuum deliveries. Parity, maternal age, gestational age, birth weight and APGAR(Activity, Pulse, Grimace, Appearance, Respiration) scores were recorded for each delivery.

Results: Vacuum extraction deliveries were conducted in 249 cases (1.24\%). The features and outcomes of the 249 vacuum assisted deliveries were as follows. Mean maternal age was $23.56 \pm 4.27$ years, and mean gestational $38.73 \pm 1.56$ weeks and mean parity was $1.95 \pm 1.57$. Mean first, and fifth minute APGAR scores of the newborns were $7.43 \pm 1.33$ and $9.24 \pm 1.29$ points respectively. Parity and birth weights were positively correlated with gestational weeks. APGAR scores observed by the first and fifth minutes were negatively correlated with parity. There was no correlation between birth weights and APGAR scores at any time point. Parity was the only effective parameter on the APGAR scores estimated at the first and fifth minutes.

Conclusions: According to the results of this study, rates of vacuum extraction delivery which have not used frequentlt in recent times were lower when compared with most of the developed countries. Incidence of cesarean section was 25.4 percent. Cesarean delivery rates were higher than the suggested cesarean rates $(15 \%)$ by World Health Organisation (WHO). Parity is the major factor that effects the APGAR scores of the neonates. Vacuum extraction delivery may be suggested more often especially for the deliveries of low parity women so as to decrease the cesarean section rates.

Key words: Vacum assisted delivery, cesarean section, APGAR score, neonatal outcome

\section{$\ddot{\mathbf{O Z}}$}

Amaç: Bu çalışmanın amacı, vakum ile doğum oranlarının belirlenmesi ve bu yöntemin gebelik sayısı ve intrauterin fötal durum ile ilişkisinin saptanmasıdır.

Yöntemler: Bu çalışmaya Diyarbakır Kadın Hastalıkları ve Doğum Hastanesi Kadın Doğum Kliniğinde 2012 yılı boyunca doğan 20050 yenidoğan katılmıştır. Bu bebeklerin 249'unda doğum sırasında vakum yöntemi uygulanmıştır. Gebelik sayısı, anne yaşı, gebelik haftası, doğum kilosu ve APGAR (Activity, Pulse, Grimace, Appearance, Respiration) skorları her bir yenidoğan için kaydedilmiştir.

Bulgular: Vakum uygulanan doğumlar tüm doğumlar arasında 1,24\% (n:249) olarak saptanmıştır. Toplam 249 vakumla doğuma ilişkin özellikler ve sonuçlar aşağıda belirtilmiştir. Ortalama anne yaşı, gebelik haftası ve parite sırasıyla $23.56 \pm 4.27$ yıl, $38.73 \pm 1.56$ hafta ve $1.95 \pm 1.57$ idi. Yenidoğanların doğum sonrası birinci ve beşinci dakikadaki APGAR skorları sırasıyla $7.43 \pm 1.33$ ve $9.24 \pm 1.29$ idi. Gebelik sayısı ve yenidoğan doğum kilusu gebelik haftası ile pozitif korelasyon göstermiştir. Birinci ve beşinci dk. APGAR skorları gebelik sayısı ile negative ilişki göstermekteydi. Yenidoğan doğum kilosu ve APGAR skorları arasında herhangi bir ilişki saptanmadı. Birinci ve beşinci dk. APGAR skorları üzerine etkili olan tek parameter gebelik sayısı olarak bulundu.

Sonuç: Vakum eşliğinde doğum son zamanlarda pek kullanılmayan bir metot olup, bu çalışmanın sonuçlarına göre vakum ile doğum oranı çoğu gelişmiş ülkeye göre düşük olarak saptanmıştır. Sezaryen oranları \% 25,4 idi. Sezaryen doğum oranları DSO tarafından önerilen oranların (15\%) oldukça üzerinde bulunmuştur. Gebelik sayısı yenidoğan APGAR skorunu etkileyen en önemli faktördür. Vakum ile doğurtma düşük gebelik sayısı bulunan kadınlarda sezaryen oranlarını da düşürmeye yönelik olarak önerilebilecek bir yöntem olabilir.
Alındığı tarih: 06.04.2016

Kabul tarihi: 26.05.2016

Yazışma adresi: Uzm. Dr. Muzaffer Temur, Bursa Şevket Yılmaz Eğitim ve Araştırma Hastanesi Kadın Hastalıkları ve Doğum Kliniği, Bursa e-mail: temurmuzaffer@gmail.com 


\section{INTRODUCTION}

Utilization of vacuum extraction device or forceps during vaginal delivery are known as operative vaginal delivery. Prolonged (longer than 120 minutes) second stage of labor, poor labor progress, maternal exhaustion, presumed fetal jeopardy are the well known indications of vacuum extraction. Inadequate cervical dilatation, low birth weight, fetal abnormalities and prematurity $(<34$ week) are the contraindications of vacuum extraction ${ }^{(1-3)}$.

In proper conditions, vacuum extraction is recognised as an effective and safe procedure in obstetrics. Vacuum- assisted delivery rates vary between countries and departments of obstetrics ${ }^{(4)}$.

Though the ideal rate of vacuum-assisted delivery remains unknown. Several studies reported vacuum extraction rates as $10-15 \%$ in UK $4.5 \%$ in USA and less than $1 \%$ in Africa ${ }^{(5-7)}$. Vacuum-assisted delivery rates seems to be higher in developed countries.

Recently increased cesarean section rates and decreased vacuum extraction rates are among the main problems of obstetrics, especially for the developing countries. In addition; vacuum extraction may help to decrease the cesarean section rate ${ }^{(4)}$. Although the literature advocates that vacuum-assisted delivery is a safe procedure and has a lower complication rate ${ }^{(8)}$, only insufficient data about vacuum-assisted delivery rates and perinatal outcomes are available for Turkish population. Aim of this study is to investigate the rate and perinatal outcome of vacuum assisted deliveries in a poorly developed region of Turkey.

\section{MATERIALS and METHODS}

This is a retrospective study which is conducted at Diyarbakır Maternity Hospital in Turkey between January 2012 to January 2013 on 20050 newborns. Two hundred and forty-four newborns were delivered with vacuum extraction. Women with singleton pregnancies who delivered at $\geq 37$ weeks of gestation in cephalic presentation through $10 \mathrm{~cm}$ cervical dilation, and underwent either attempted operative vaginal delivery through forceps or vacuum extraction or cesarean delivery without trial of operative vaginal delivery were included in the study. Women with pregnancies complicated by severe anomalies, antepartum or intrapartum stillbirth and prolonged second stage of labor more than 12 hours were excluded. Parity, maternal age, duration of pregnancy, birth weight and APGAR scores were recorded for each delivery. Only low or outlet operative vaginal deliveries were performed. APGAR scores were recorded by a pediatricien who examined the infants at the labor room for all deliveries.

\section{Statistical analysis}

SPSS version 11.5 was used for statistical analysis. Descriptive statistics (mean \pm standard deviation, percentages) were evaluated and one sample t-test was used to compare the mean values. The relationship between the variables was examined by Pearson correlation. Multivariable linear regression analysis was performed to examine the effect of parity, fetal weight and gestational age on APGAR scores. $\mathrm{P}<0.05$ was considered as statistical significance.

\section{RESULTS}

During this study period 20050 newborns delivered vaginally. Cesarean section rate were $25.4 \%$ $(n=5093)$ and $11.8 \%$ of them were primary cesarean sections. Vacuum extraction was conducted in 249 cases (1.24\%). Mean maternal and gestational ages were $23.56 \pm 4.27$ years , and $38.73 \pm 1.56$ weeks, respectively. Mean parity was $1.95 \pm 1.57$. Mean APGAR scores of the newborns were $7.43 \pm 1.33$ at the first

Table 1. Analysis of the maternal and neonatal demographic variables.

\begin{tabular}{lc}
\hline & Mean \pm Standart deviation \\
\hline Maternal Age (years) & $23.56 \pm 4.27$ \\
Gestational Age (weeks) & $38.73 \pm 1.56$ \\
Parity & $1.95 \pm 1.57$ \\
APGAR Score 1. Minute & $7.43 \pm 1.33$ \\
APGAR Score 5. Minute & $9.24 \pm 1.29$ \\
\hline
\end{tabular}

One sample t test is used to calculate the mean values. 
and 9.24 \pm 1.29 at the fifth minutes (Table 1).

APGAR score was $>6$ in $220(89,2 \%)$ newborns at the first and $236(94.8 \%)$ at the fifth minutes (Table 2).

Table 2. Frequency of the APGAR scores.

\begin{tabular}{lccc}
\hline & APGAR score & N & $\%$ \\
\hline 1. minute & $1-3$ & 11 & 4,4 \\
& $4-6$ & 16 & 6,4 \\
5. minute & 7 and more & 222 & 89,2 \\
& $1-3$ & 3 & 1,2 \\
& $4-6$ & 10 & 4 \\
& 7 and more & 236 & 94,8 \\
& Total & 249 & 100 \\
\hline
\end{tabular}

Parity $(r=0.94 ; p<0.001)$, gestational age $(r=0.23$; $\mathrm{p}<0.001)$ and neonatal birth weight $(\mathrm{r}=0.26 ; \mathrm{p}<0.001)$ were significantly, and positively correlated and APGAR score at first minute $(\mathrm{r}=-0.13 ; \mathrm{p}=0.003)$ was significantly, but negatively correlated with maternal age. There was no significant correlation between maternal age and APGAR score at the fifth $(\mathrm{r}=-0.12$; $\mathrm{p}=0.06$ ) minutes (Table 3 ).

Table 3. Pearson Correlation analysis of the relationship between the variables.

\begin{tabular}{lcccccc}
\hline & & $\begin{array}{c}\text { Maternal } \\
\text { Age }\end{array}$ & $\begin{array}{c}\text { Gestational Parity } \\
\text { Age }\end{array}$ & $\begin{array}{c}\text { Fetal } \\
\text { Weight }\end{array}$ & $\begin{array}{c}\text { 1.Minute } \\
\text { APGAR } \\
\text { Score }\end{array}$ \\
\hline Maternal Age & $\mathrm{R}$ & 1,00 & 0,23 & 0,94 & 0,26 & $-0,13$ \\
& $\mathrm{P}$ & & $<0.001$ & $<0.001$ & $<0.001$ & 0,03 \\
Gestational Age & $\mathrm{R}$ & 0,23 & 1,00 & 0,24 & 0,96 & 0,01 \\
& $\mathrm{P}$ & $<0.001$ & & $<0.001$ & $<0.001$ & 0,91 \\
Parity & $\mathrm{R}$ & 0,94 & 0,24 & 1,00 & 0,28 & $-0,20$ \\
& $\mathrm{P}$ & $<0.001$ & $<0.001$ & & $<0.001$ & $<0.001$ \\
Fetal Weight & $\mathrm{R}$ & 0,26 & 0,96 & 0,28 & 1,00 & $-0,01$ \\
& $\mathrm{P}$ & $<0.001$ & $<0.001$ & $<0.001$ & & 0,98 \\
1. Minute & $\mathrm{R}$ & $-0,13$ & 0,01 & $-0,20$ & 0,00 & 1,00 \\
APGAR Score & $\mathrm{P}$ & 0,03 & 0,91 & $<0.001$ & 0,98 & \\
5. Minute & $\mathrm{R}$ & $-0,12$ & 0,06 & $-0,19$ & 0,05 & 0,89 \\
APGAR Score & $\mathrm{P}$ & 0,06 & 0,38 & $<0.001$ & 0,40 & $<0.001$ \\
& & & & & & \\
\hline
\end{tabular}

Parity $(\mathrm{r}=0.24 ; \mathrm{p}<0.001)$, and neonatal birth weights $(r=0.96 ; p<0.001)$ were positively correlated with gestational age. No significant correlation was found between gestational age and APGAR scores $(\mathrm{p}>0.05)$. APGAR scores at the first $(r=-0.2)$ and fifth minutes $(\mathrm{r}=-0.19)$ were negatively, and neonatal birth weights $(r=0,28)$ were positively correlated with parity $(\mathrm{p}<0.001)$. There was no significant correlation between neonatal birth weights and APGAR scores at any time point $(\mathrm{p}>0.05)$ (Table 3$)$.

Parity was the only effective parameter on the APGAR scores at both first and fifth minutes (Table 4 and 5).

Table 4. Multivariable regression analysis about the effect of independent variables (Gestational age, Parity and Fetal Birth Weight) on the 1. Minute APGAR scores as a dependent variable.

\begin{tabular}{lcc}
\hline & Beta & P \\
\hline Gestational Age & $-0,03$ & 0,88 \\
Parity & $-0,22$ & $<0,001$ \\
Fetal Weight & 0,14 & 0,90 \\
\hline
\end{tabular}

Table 5. Multivariable regression analysis about the effect of independent variables (Gestational age, Parity and Fetal Birth Weight) on the 5. Minute APGAR scores as a dependent variable.

\begin{tabular}{lcc}
\hline & Beta & P \\
\hline Gestational Age & $-0,03$ & 0,90 \\
Parity & $-0,22$ & $<0,001$ \\
Fetal Weight & 0,14 & 0,53 \\
\hline
\end{tabular}

\section{DISCUSSION}

This is the first study which describes the vacuumassisted vaginal delivery rate in Turkey.

Vacuum assisted delivery is a unique form of operative deliveries which is used to shorten the second period of the labor. Several studies showed the association between fetal mortality and prolonged second period of the labor ${ }^{(1,2)}$. In our study vacuum- assisted delivery rate was lower than developed countries. For example vacuum-extraction delivery rates are reportedly $10-15 \%$ in UK and $4.5 \%$ in the USA ${ }^{(5,6)}$. On the other hand our data were similar to those of the African countries where the vacuum rate is less than one percent ${ }^{(7)}$. Vacuum-extraction delivery becomes a more popular method in developed countries. Sanhal et al. ${ }^{(8)}$ reported in their review article that vacuum-assisted delivery rates for Turkish population is still unknown. In this study, vacuum-assisted, and cesarean delivery rates were $1.24 \%$ and 25.4 , respectively. The lower vacuum-assisted delivery rates seem to be associated with cesarean section rates higher than those suggested by WHO ${ }^{(9-11)}$. 
The complications of vacuum- assisted deliveries usually occur during early postnatal period. APGAR scoring system is a well known indicator for fetal wellbeing. In this study $5^{\text {th }}$ minute-APGAR scores were higher than $7^{\text {th }}$ minute-Apgar scores in $\% 94.8$ of neonates. This result indicates the safety of vacuumextraction delivery.

Several studies showed the relationship between operative delivery and poor neonatal outcomes ${ }^{(12-16)}$. Sekeroglu et al. ${ }^{(17)}$ and Baser et al. ${ }^{(18)}$ reported that higher maternal age is associated with decreased APGAR scores and poor neonatal outcomes. In this study maternal age was negatively correlated with $1^{\text {th }}$ minute-APGAR scores but there was no significant correlation with $5^{\text {th }}$ minute APGAR scores, and material age.

Higher number of parity is a well known parameter which is associated with low APGAR scores and poor neonatal outcomes ${ }^{(19-21)}$. But there is still a lack of data about the relationship between parity and neonatal outcomes related to vacuum-assisted deliveries. Our data showed that higher parity is negatively correlated with APGAR scores. Parity is also one of the most effective factors on the APGAR score. Anemia, uterine atony and chronic diseases may explain the association between multiparity and low APGAR scores ${ }^{(21)}$.

There are conflicted results in several studies about the effect of parity on the neonatal birth weights. Low birth weight due to high parity is defined in the final declaration of Turkey Demographic and Health Survey (TDHS) $2008{ }^{(9)}$. Kılıç et al. ${ }^{(22)}$ reported the rates of low birth weight newborns as $\% 9.8$ for primipar, $\% 10.2$ for multipar and $\% 17.3$ for grandmultipar mothers. Conversely Babinzki et al. ${ }^{(20)}$ and Juntunen et al. ${ }^{(23)}$ reported that increased parity is related with high-birth weight newborns. There was a positive correlation between the number of parities and neonatal birth weight in this study.

As a conclusion, vacuum-extraction delivery rates are found to be lower than most of the developed countries. Average APGAR score of the neonates were good $1^{\text {th }}$ and $5^{\text {th }}$ minutes. Parity is the major factor that effects the APGAR score of the neonates. Vacuum- assisted delivery should be encouraged in low parity women so as to decrease the cesarean section rates.

\section{Disclosure statement}

The authors declare that there are no conflicts of interest.

\section{Acknowledgement section}

The authors are grateful to Dr. Hasan Taylan YILMAZ due to his valuable contributions for the statistical analysis. This study did not receive any specific grant from any funding agency in the public, commercial or not-for-profit sector. This study was supported by Şükrü BUDAK.

\section{REFERENCES}

1. Cohen WR. Influence of the duration of second stage labor on perinatal outcome and puerperal morbidity. Obstet Gynecol 1977;49:266-269.

2. Gerber S, Vial Y, Hohlfield P. Maternal and neonatal prognosis after a prolonged second stage of labor. J Gynecol Obstet Biol Reprod 1999;28:145-150.

3. Martin JA, Hamilton EB, Sutton PD. Centers for disease control and prevention national center for health statistics national vital statistics system. Births: final data for 2002. Nat Vital Stat Rep 2007;56:1-103.

4. Okeke TC, Ekwuazi KE. Is there still a place for vacuum extraction (ventouse) in modern obstetric practice in Nigeria. Ann Med Health Sci Res 2013;3:471-474. http://dx.doi.org/10.4103/2141-9248.122043

5. Royal College of Obstetricians and Gynaecologists. Operative vaginal delivery (Guideline 26), 2005. [Cited 17 Jan 2013].

6. Martin JA, Hamilton BE, Sutton PD, Ventura SJ, Menacker F, Kirmeyer S, et al . Births: final data for 2006. Natl Vital Stat Rep 2009;57:1-102.

7. Bailey PE. The disappearing art of instrumental delivery: Time to reverse the trend. Int J Gynaecol Obstet 2005;91:89 96.

http://dx.doi.org/10.1016/j.ijgo.2005.05.016

8. Sanhal CY, Kazandı M, Itil IM. Vaginal delivery with vacuum extraction. J Turk Soc Obstet Gynecol 2011;8:231-237. http://dx.doi.org/10.5505/tjod.2011.94546

9. Hacettepe University İnstitute of population studies (TDHS) 2008 Turkey Demographic and Health Survey 2008; 24-160.

10. Osterman MJ, Martin JA. Primary cesarean delivery rates, by state: results from the revised birth certificate, 2006-2012. Natl Vital Stat Rep 2014;63:1-11.

11. Costa A, Policiano C, Clode N, M Graça L. Indications for cesarean deliveries during a 7-year period in a tertiary hospital. Acta Med Port 2013;26:649-654.

12. Waldenström U, Aasheim V, Nilsen AB, Rasmussen S, 
Pettersson HJ, Shytt E. Adverse pregnancy outcomes related to advanced maternal age compared with smoking and being overweight. Obstet Gynecol 2014;123:104-112. http://dx.doi.org/10.1097/AOG.0000000000000062

13. Klemetti R, Gissler M, Sainio S, Hemminki E. Associations of maternal age with maternity care use and birth outcomes in primiparous women: a comparison of results in 1991 and 2008 in Finland. BJOG 2014;121:356-362. http://dx.doi.org/10.1111/1471-0528.12415

14. Barton JR, Sibai AJ, Istwan NB, Rhea DJ, Desch CN, Sibai BM. Spontaneously Conceived Pregnancy after 40: Influence of Age and Obesity on Outcome Am J Perinatol 2013 Dec 11. [Epub ahead of print]

15. Paçarada M, Zeqiri F, Hoxha S, Dervishi Z, Kongjeli N, Kongjeli G, Impact of parity and intrauterine fetal condition during vacuum extraction. Qavdarbasha HMed Arh 2010;64:175-177.

16. Hiraizumi Y, Miura A, Miyake H, Suzuki S. Perinatal outcomes of failed vacuum extraction. J Nippon Med Sch 2012;79:280-283. http://dx.doi.org/10.1272/jnms.79.280

17. Şekeroğlu M, Baksu A, İnce Z, Gültekin H, Göker N, Özsoy S. Adolescent and old age pregnants obstetric. Şişli Etfal Hast Tıp Bülteni 2009;43:1-7.

18. Başer E, Seçkin KD, Erkılınç S, Karslı MF, Yeral İM, Kaymak O, Çağlar T,Danışman N. The impact of parity on perinatal outcomes in pregnancies complicated by advanced maternal age. J Turkish-German Gynecol Assoc 2013;14:205209. http://dx.doi.org/10.5152/jtgga.2013.62347

19. Mgaya AH, Massawe SN, Kidanto HL, Mgaya HN. Grand multiparity: is it still a risk in pregnancy? BMC Pregnancy Childbirth 2013;13:241.

20. Babinszki A, Kerenyi T, Torok O, Grazi V, Lapinski RH, Berkowitz RL. Perinatal outcome in grand and great-grand multiparity: effects of parity on obstetric risk factors. Am J Obstet Gynecol 1999;181:669-674. http://dx.doi.org/10.1016/S0002-9378(99)70511-9

21. Teguete I, Maiga AW, Leppert PC. Maternal and neonatal outcomes of grand multiparas over two decades in Mali. Acta Obstet Gynecol Scand 2012;91:580-586. http://dx.doi.org/10.1111/j.1600-0412.2012.01372.

22. Kılıç S, Uçar M, Temir P, Erten Ü, Şahin E, Karaca B,Yüksel $\mathrm{S}$, Özkır F. The Frequency and Influencing Factors of Antenatel Care in Pregnant Women. TAF Preventive Medicine Bulletin 2007;6:91-97.

23. Juntunen K, Kirkinen P, Kauppila A. The clinical outcome in pregnancies of grand grand multiparous women. Acta Obstet Gynecol Scand 1997;76:755-759. http://dx.doi.org/10.3109/00016349709024342

24. Větr M. High birthweight births at University Hospital Olomouc (1993-2010). Ceska Gynecol 2012;77:579-588. 